\title{
Some explanatory Notes to Mr. H.M.Fraser's Article about Moufet's Theatrum Insectorum
}

\author{
by Bernhard Milt M.D.
}

News about the entomological inheritance of Conrad Gessner in the biographic works concerning this important natural philosopher are very insufficient and of ten incorrect. In the best known biographies, J. Hanhart, Conrad Gessner (Winterthur 1824) and W. Ley Conrad Gessner, Leben und Werk (München 1929) his entomological work is not even mentioned; but Mähli reports in the "Allgemeine Deutsche Biographie» (vol. 9. p. 117) that by means of Camerarius this inheritance arrived to England and into the possession of Thomas Moufet who took Gessner's notes into his Historia Insectorum. Under the name of Moufet the Theatrum Insectorum which has been published in London in 1634 is nowadays still catalogised in most of the Swiss libraries. Therefore an exact knowledge of the fate of this inheritance is by all means desirable.

It is certainly wrong to think that we have no exact knowledge about Gessner's entomological work in German literature; it can be found in scriptures hardly consulted by medical historians. The best description we could find is that in the unfortunately unfinished work of the Freiburg zoologist and polyhistorian Robert Lauterborn: «Der Rhein» in which first volume (Freiburg 1930), p. 136-138, in the chapter upon «Konrad Geßner und die Tierkunde» we probably have the best representation of Gessner as a zoologist. In this work are also mentioned former representations of Burmeister in his «Handbuch der Entomologie», vol. 1 (1832), p. 660 and vol. 2, (1835), p. 5 and of H. A. Hagen in the «Bibliotheca entomologica» vol. 1 (1862), p. 553/4.

How the entomological inheritance of Gessner got into the possession of Penny is not quite clear. According to some notes in the above mentioned German literature it went first to Camerarius, together with Gessner's botanical work. The Nuremberg town physician and natural philosopher Joachim Camerarius jun. bought the botanical papers in 1581 for the sum of 175 florins from Kaspar Wolf in Zurich, who had acquired it for the same sum from the heirs of his master. Wolf had been nominated by Gessner in his hour of death to be the executor of his literary testament and consequently he endeavoured to publish the projected «Historia plantarum», as he published several other manu- 
scripts of Gessner's. But this task surpassed his powers. Camerarius too had been personally acquainted with Gessner; he sent him different plants, especially from Italy. But according to English reports the entomological work of Gessner had got directly into the possession of Penny (Dictionary of Biography, vol. 44, 1895, p. 337). - Penny knew Gessner personally and visited him at Zurich. He was a great expert of plants with exact knowledge not only of the English flora, but also of the country of Orléans, the Mt Salève, Môle, and the Swiss Jura. He seems to have advised Wolf in the projected edition of the Historia plantarum and to have staid in Zurich for the last time in 1568. The left work of Gessner's plant work is enriched by many notes in Penny's hand. He seems to have been estimated as one of Gessner's special friends. When Rudolf Zwingli, a grandson of the reformator fell deadly ill in England in the year 1576 he was treated as well by Gessner's friend William Turner as by Penny (Zwingliana vol. 1 1904, p. 257). The possibility that Wolf gave Gessner's entomological work directly to Penny may therefore not be excluded.

Moufet had also relations to Switzerland. He disputed on $31^{\text {st }}$ May 1578 under Felix Platter in Basle «de venis mesaraicis obstructis ipsarumque ita affectarum curatione». His dissertation of $20^{\text {th }}$ December 1578 «De anodinis medicamentis eorumque causis et usibus physica et medica consideratio» is still to be found in the university library of Basle (F.Husner, Verzeichnis der Basler medizinischen Universitätsschriften von 1575-1829. Festschrift J. Brodbeck-Sandreuter, Basel 1942. p. 159). Biographical notes upon Thomas Moufet are to be found in the Dictionary of Biography, vol. 38 (1894), p. 101.

Mayerne was Swiss, a knowledge which evidently failed to Lauterborn who otherwise as a faithful friend of our country would certainly have noted this fact. His real name was Théodore Turquet de Mayerne. He was born in Geneva in 1573 and died in Chelsea in 1655. His father had come to Geneva in 1572 as a protestant refugee. The surname of de Mayerne had been taken over from an estate, which the family owned in the neighbourhood of Geneva. Mayerne is said to have been the chief physician to Henri IV (of France) and the Duc de Rohan, and also to have treated Louis XIII. Because of his protestantic confession he later emigrated to England where he became the chief physician to James I and Charles I. As a physician he strongly followed the chemiatric direction. With his native town Geneva he always remained in connection; 
the university library possesses a portrait of him, which is attributed to Rubens. His most famous secret remedy got after his death into the possession of the Geneva physician Colladon. Detailed biographical notes of this interesting man who published the Theatrum Insectorum in London in 1634 can be found in the "Biographie générale», Paris (1860), vol. 33 , p. $544-546$.

\section{Die Augsburger erneuerte Hebammenordnung von 1750}

Alte Hebammenordnungen und «Hebammenschulen» sind in größerer Zahl erhalten geblieben, ich erinnere an diejenige des Eucharius Roeßlin (1513), des Ortollfus (1500); etwas später erschien der «Rosengarten» des Straßburger «Chirurgen» Walter Reiff, (Rivius) von 1545, dann jener von Steinschneider (1554). Dann kam das bedeutend wertvollere «Trostbüchli» des Zürchers Jakob Rueff (1554). Im 17. Jahrhundert folgte die «Hebammenschul» des Christoph Völtern in Württemberg (1627), die "Chur-Brandenburgische Hof-Wehe-Mutter» der Justine Siegemundin (1690), die "Morgenröte der Hebammen» (1696) Hendrik van Deventers (1651-1724); im 18. Jahrhundert endlich neben vielen andern die «Helvetisch-Vernünftige Wehemutter» des Johann Fatio (1752). Sie alle teilen vielfach das Schicksal ihrer nachgeborenen Schwestern bis auf unsere Tage, insofern sie nämlich mehr oder minder gleich lauten und in irgendeiner Form schon Gesagtes wiederbringen. Die Augsburgerordnung vom Jahre 1750 macht insofern eine Ausnahme, als sie durch Eigenart und Umfang besonders medizin-historisches Interesse beanspruchen darf. Es ist tatsächlich ein kleines Buch von nicht weniger als 95 Seiten, um das es sich hier handelt, das auf alle Details und kasuistischen Möglichkeiten weitgehend Rücksicht nimmt und uns damit einen wertvollen Einblick vermittelt in die hohe Bedeutung, die schon vor 200 Jahren einsichtige Behörden einer zweckmäßigen Geburtshilfe beimaßen. Gedruckt ist der Erlaß beim Augsburger Stadtbuchdrucker Andreas Bringhausser. Die amtliche Gutheißung ist datiert vom 1. Juli 1749. Sie nimmt ausdrücklich Bezug auf eine "bisherige der Verbesserung wohl nötige Verordnung» und richtet sich sowohl an die «liebe Burgerschaft» als an «die obrig- 